\title{
PENGARUH KUALITAS SDM, ETIKA PROFESI, DAN KOMITMEN ORGANISASI TERHADAP KINERJA AUDITOR (Studi Empiris Pada Kantor Akuntan Publik di Jakarta Selatan)
}

Oleh :

\author{
Galih Chandra Kirana
}

\begin{abstract}
The purposive of this research is to know the influence of quality of human reseorces, professional ethics, and organizational commitment to auditor performance. The population in this research is the auditorwho works in serveral Public Accountant Office in South Jakarta area wich is listen in the Directory Indonesia Institute of Certified Public Accountants (IICPA). The sample used in this research were 50 respondents from 7 Public Accounting Firm. The data of this research are primary data obtained trough the distribution of questionnaires. The sampling technique use purposive sampling method, while the data processing method used by the researcher of multiple liniear analysis with the help of SPSS version 21. The result of this research indicate that the organizational commitment partially have influence to auditor performance, where as quality of human reseorces and professional ethics had no influence to auditor performance.
\end{abstract}

The key word : Quality of Human Reseorces, Professional Ethics, Organizational Commitment, Auditor Performance.

\begin{abstract}
ABSTRAK
Tujuan penelitian ini adalah untuk mengetahui pengaruh kualitas sdm, etika profesi, komitmen organisasi terhadap kinerja auditor. Populasi dalam penelitian ini adalah auditor yang bekerja di Kantor Akuntan Publik wilayah Jakarta Selatan yang terdaftar di Direktoreat Institut Akuntan Publik Indonesia (IAPI). Sampel yang digunakan pada penelitian ini sebanyak 50 responden dari 7 Kantor Akuntan Publik. Data penelitian ini adalah data primer yang diperoleh melalui penyebaran kuesioner. Teknik pengambilan sampel menggunakan purposive sampling, sedangkan metode pengolahan data yang digunakan peneliti adalah analisis linear berganda dengan bantuan SPSS versi 21. Hasil penelitian ini menunjukan bahwa komitmen organisasi secara parsial berpengaruh terhadap kinerja auditor. Sedangkan kualitas sdm dan etika profesi tidak berpengaruh terhadap kinerja auditor.
\end{abstract}

Kata Kunci : Kualitas SDM, Etika Profesi, Komitmen Organisasi, Kinerja Auditor. 


\section{PENDAHULUAN}

\section{Latar Belakang Penelitian}

Kinerja auditor menurut Mulyadi (2014) adalah akuntan publik yang melaksanakan penugasan pemeriksaan (examination) secara obyektif atas laporan keuangan suatu perusahaan atau organisasi lain dengan tujuan untuk menentukan apakah laporan keuangan tersebut menyajikan secara wajar sesuai dengan prinsip akuntansi yang berlaku umum, dalam semua hal yang material, posisi keuangan dan hasil usaha perusahaan. Auditor yang mengaudit laporan keuangan perusahaan disebut dengan auditor swasta atau auditor eksternal. Auditor eksternal bekerja pada Kantor Akuntan Publik. Tugas auditor eksternal adalah memberikan pendapat atas kewajaran laporan keuangan dan melaporkan kesimpulan dari hasil pemeriksaan yang dilakukan. Pengauditan dilakukan pada perusahaan go public, serta dilakukan pula pada perusahaan-perusahaan besar dan perusahaan kecil yang berfokus dalam mencari laba. Dalam etika profesi akuntan publik terdapat prinsip etika yaitu tanggung jawab bahwa laporan keuangan yang telah diaudit oleh akuntan publik bebas dari salah saji material, dapat dipercaya kebenarannya untuk dijadikan sebagai dasar pengambilan keputusan dan telah sesuai dengan prinsip-prinsip akuntansi yang berlaku di Indonesia. Oleh karena itu diperlukan suatu jasa profesional yang independen dan obyektif untuk menilai kewajaran laporan keuangan yang disajikan oleh manajemen.

Permasalahan mengenai rendahnya kualitas auditor menjadi salah satu fokus masyarakat dalam beberapa tahun terakhir. Salah satunya adalah Kasus yang menimpa perusahaan Toshiba pada tahun 2015 yang melakukan manipulasi laporan keuangan yang melibatkan auditor dalam kecurangan tersebut sehingga menyebabkan laporan keuangan tersebut tidak berkualitas. KAP yang mengaudit laporan keuangan Toshiba yaitu Ernst \& Young Shin Nihon LLC.EY telah bekerja sama melakukan audit untuk Toshiba selama 12 tahun terhitung sejak tahun 2002 hingga 2014 tidak mampu menemukan serta melaporkan kalau perusahaan ini ternyata melakukan kecurangan. Atas kejadian tersebut, regulator keuangan Jepang akan mendenda perusahaan afiliasi Ernst \& Young sebesar 2,1 miliaryen (US\$17,4 juta) setelah lembaga tersebut gagal melihat penyimpangan standar akuntansi di Toshiba sertaakan menangguhkan Ernst \& Young dalam mengambil kontrak bisnis baru selama tiga bulan (Kompas.com, 2016).

Berdasarkan fenomena tersebut menggambarkan bahwa masih banyak laporanlaporan keuangan yang tidak berkualitas, sehingga membuat menurunya kinerja auditor.

Dalam penelitian ini kinerja auditor berkaitan dengan kualitas sumber daya manusia, etika profesi dan, komitmen organisasi. Dimana kualitas sumber daya manusia Menurut Menurut Danim (2013) adalah sumber daya yang memenuhi kriteria kualitas fisik dan kesehatan, kualitas intelektual (pengetahuan dan keterampilan), dan kualitas mental spiritual (kejuangan). Auditor yang memiliki pemahaman yang rendah terhadap tugas dan fungsinya, serta hambatan yang ditemukan dalam pengolahan data juga akan berdampak pada penyajian laporan keuangan. Sumber daya manusia yang berkualitas dapat menghemat waktu pembuatan laporan keuangan, disebabkan karena sumber daya manusia tersebut telah mengetahui dan memahami apa yang akan dikerjakan dengan baik dan sesuai bidangnya sehingga penyajian laporan keuangan bisa tepat waktu. Semakin cepat waktu penyajian laporan keuangan, maka semakin baik untuk pengambilan keputusan (Roshanti, 
Sujana, \& Sinarwati, 2014). Sumber Daya Manusia merupakan human capital di dalam organisasi. Human capital merupakan pengetahuan, ketrampilan, dan kemampuan seseorang yang dapat digunakan untuk menghasilkan layanan profesional. Human capital merupakan sumber inovasi dan gagasan. Auditor dengan human capital tinggi lebih memungkinkan untuk memberikan layanan yang konsisten dan berkualitas tinggi. Kompetensi sumber daya manusia adalah kemampuan sumber daya manusia untuk melaksanakan tugas dan tanggungjawab yang diberikan kepadanya dengan bekal pendidikan, pelatihan, dan pengalaman yang cukup memadai. Sumber daya manusia (SDM) yang kompeten tersebut akan mampu memahami logika akuntansi dengan baik.

Adapun menurut Ni Made Regina Amandani \& Made Gede Wirakusuma (2017) menyatakan bahwa komitmen organisasi memiliki pengaruh positif terhadap kinerja auditor. Sedangkan Saputro Nugroho Widhi \& Dr. Erma Setyawati, Ak, M.M., (2015) menyatakan hasil yang berlawanan yaitu Komitmen organisasi berpengaruh positif dan signifikan pada kinerja auditor.

Berdasarkan uraian latar belakang diatas, maka penulis tertarik untuk meneliti mengenai kepuasan klien terhadap auditor dengan judul : "Pengaruh Kualitas Sumber Daya Manusia, Etika Profesi, dan Komitmen Organisasi Terhadap Kinerja Auditor Pada Kantor Akuntan Publik (KAP) Jakarta Selatan."

\section{Permusan Masalah}

Berdasarkan uraian dalam latar belakang penelitian, tentang pengaruh kualitas sumber daya manusia, etika profesi, dan komitmen organisasi terhadap kinerja auditor. Maka masalah penelitian ini dapat dirumuskan sebagai berikut :

1. Apakah terdapat pengaruh kualitas sumber daya manusia terhadap kinerja auditor?

2. Apakah terdapat pengaruh etika profesi terhadap kinerja auditor?

3. Apakah terdapat pengaruh komitmen organisasi terhadap kinerja auditor?

\section{LANDASAN TEORI}

\section{Auditing}

Menurut Mulyadi (2014:9) pengertian auditing adalah :

Suatu proses sistematik untuk memperoleh dan mengevaluasi bukti objekif mengenai pernyataan-penyataan tentang kegiatan dan kejadian ekonomi, dengan tujuan untuk menetapkan tingkat kesesuaian antara pernyataan-pernyataan tersebut dengan criteria yang telah ditetapkan, serta penyampaian hasil-hasil kepada pemakai yang berkepentingan.

Menurut Sukrisno (2016:4) pengertian auditing adalah :

Suatu pemeriksaan yang dilakukan secara kritis dan sistematis oleh pihak yang independen, terhadap laporan keuangan yang telah diusun oleh manajemen beserta catatan-catatan pembukuan dan bukti-bukti pendukungnya dengan tujuan untuk memberikan pendapat mengenai kewajaran laporan keuangan. 


\section{Standar Auditing}

Menurut Arens et.al (2012:42) menyatakan bahwa "Standar auditing merupakan pedoman umum untuk membantu auditor memenuhi tanggungjawab profesionalnya dalam audit atas laporan keuangan historis.Standar ini mencakup pertimbangan mengenai kualitas profesional seperti kompetensi dan independensi, persyaratan pelaporan dan bukti”.

Standar auditing menurut Mulyadi (2014:16) mengharuskan auditor menyatakan apakah menurut pendapatnya, laporan keuangan disajikan sesuai prinsip akuntansi yang berlaku umum di Indonesia dan jika ada, menunjukan adanya ketidakkonsistenan penerapan prinsip akuntansi dalam penyusunan laporan keuangan periode berjalan dibandingkan dengan penerapan prinsip akuntansi tersebut dalam periode sebelumnya.

\section{Jenis-Jenis Auditor}

Menurut Mulyadi (2014:28) orang atau kelompok yang melaksanakan audit dapat dikelompokan menjadi tiga golongan: auditor independen, auditor pemerintah, dan auditor intern. berikut:

Adapun penjelasan dari jenis-jenis auditor menurut Mulyadi tersebut adalah sebagai

1. Auditor independen

Auditor professional yang menyediakan jasanya bagi masyarakat umum, terutama dalam bidang audit atas laporan keuangan yang dibuat oleh kliennya.

2. Auditor pemerintah

Auditor professional yang bekerja di instansi pemerintah yang tugas pokoknya melakukan audit atas pertanggungjawaban keuangan yang disajikan oleh unit-unit organisasi atau entitas pemerintah atau pertanggungjawaban keuangan yang ditujukan kepada pemerintah.

3. Auditor internal

Auditor yang bekerja dalam perusahaan (perusahaan negara maupun perusahaan swasta) yang tugas pokoknya adalah menentukan apakah kebijakan dan prosedur yang ditetapkan oleh manajemen puncak telah dipatuhi, menentukan baik atau tidaknya penjagaan terhadap kekayaan organisasi, menentukan efisiensi dan efektivitas prosedur kegiatan organisasi, serta menentukan keandalan informasi yang dihasilkan oleh berbagai bagian organisasi.

\section{Jenis-jenis Audit}

Menurut Mulyadi (2014:30) audit umumnya digolongkan menjadi 3 golongan: audit laporan keuangan, audit kepatuhan, audit operasional.

1. Audit Laporan Keuangan

Audit laporan keuangan adalah audit yang dilakukan oleh auditor independensi terhadap laporan keuangan yang disajikan oleh klienya untuk menyatakan pendapat mengenai kewajaran laporan keuangan tersebut. Hasil audit terhadap laporan keuangan tersebut disajikan dalam bentuk tertulis berupa laporan audit, laporan audit ini dibagikan kepada para pemakai informasi keuangan seperti pemegang saham, kreditur, dan Kantor Pelayanan Pajak. 
2. Audit Kepatuhan

Audit kepatuhan adalah audit yang tujuanya untuk menentukan apakah yang diaudit sesuai dengan kondisi atau peraturan tertentu. Hasil audit kepatuhan umumnya dilaporkan kepada pihak yang berwenang membuat kriteria. Audit kepatuhan banyak dijumpai dalam pemerintahan.

3. Audit Operasional

Audit operasional merupakan review secara sistematik kegiatan organisasi, atau bagian dari padanya, dalam hubungan dengan tujuan tertentu. Tujuan audit operasional adalah untuk:

a. Mengevaluasi Kinerja.

b. Mengidentifikasi kesempatan untuk peningkatan.

c. Membuat rekomendasi untuk perbaikan atau tindakan lebih lanjut.

Pihak yang memerlukan audit operasional adalah manajemen atau pihak ketiga. Hasil audit operasional diserahkan kepada pihak yang meminta dilaksanakanya audit tersebut.

\section{Prosedur Audit}

Mulyadi (2014:86) mendefinisikan prosedur audit adalah "instrument runcuan untuk mengumpulkan tipe bukti audit tertentu yang harus diperoleh pada saat tertentu dalam audit”.

Prosedur audit yang biasa dilakukan oleh auditor meliputi:

1. Inspeksi.

Inspeksi merupakan pemeriksaan secara rinci terhadap dokumen atau kondisi fisik sesuatu. Prosedur audit ini banyak dilakukan oleh auditor. Dengan melakukan inspeksi terhadap sebuah dokumen, auditor akan dapat menentukan keaslian dokumen tersebut. Dengan melakukan inspeksi terhadap kondisi fisik suatu aktiva tetap mislanya, auditor akan dapat memperoleh informasi mengenai eksistensi dan keadaan fisik aktiva tersebut.

\section{Pengamatan (observation).}

Pengamatan dan observasi merupakan prosedur audit yang digunakan oleh auditor untuk melihat atau menyaksikan pelaksanaan suatu kegiatan. Dengan pengamatan ini auditor akan dapat memperoleh bukti visual mengenai pelaksanaan suatu kegiatan. Objek yang diamati auditor adalah karyawan, prosedur, dan proses.

3. Konfirmasi.

Konfirmasi merupakan bentuk penyelidikan yang memungkinkan auditor memperoleh informasi secara langsung dari pihak ketiga yang bebas. Prosedur yang biasa ditempuh oleh auditor dalam konfirmasi ini adalah sebagai berikut:

a) Auditor menerima klien untuk menanyakan informasi tertentu kepada pihak luar.

b) Klien meminta kepada pihak luar yang ditunjuk oleh auditor untuk memberikan jawaban langsung kepada auditor mengenai informasi yang ditanyakan oleh auditor tersebut. 
c) Auditor meneruma jawaban langsung dari pihak ketiga tersebut.

4. Permintaan Keterangan.

Permintaan keterangan merupakan prosedur audit yang dilakukan dengan meminta keterangan secara lisan. Bukti audit yang dihasilkan dari prosedur ini adalah bukti lisan dan bukti dokumen.

5. Penelusuran.

Auditor melakukan penelusuran informasi sejak mula-mula data tersebut direkam pertama kali dalam dokumen, dilanjutkan dengan pelacakan pengolahan data tersebut dalam proses akuntansi.

Prosedur audit ini terutama ditetapkan terhadap bukti documenter.

6. Pemeriksaan dokumen pendukung.

Pemeriksaan dokumen pendukung (vouching) merupakan prosedur audit yang meliputi:

a) Inspeksi terhadap dokumen-dokumen yang mendukung suatu transaksi atau data keuangan untuk menentukan kewajaran dan kebenaranya.

b) Perbandingan dokumen tersebut dengan catatan akuntansi yang berkaitan.

Prosedur audit ini berlawanan arahnya dengan prosedur penelusuran. Dalam penelusuran auditor bertolak dari dokumen kemudian mengusut pencatatanya ke dalam catatan-catatan akuntansi yang berkaitan, sedangkan dalam vouching, auditor bertolak dari catatan akuntansi, kembali memeriksa dokumen-dokumen yang mendukung informasi yang dicatat dalam catatan tersebut.

7. Perhitungan (counting)

Prosedur ini meliputi :

a) Perhitungan fisik terhadap sumber daya berwujud seperti kas atau persediaan ditangan.

b) Pertanggungjawaban semua formulir bernomor urut tercetak.

Perhitungan fisik digunakan untuk mengevaluasi bukti fisik kuantitas yang ada ditangan, sedangkan pertanggungjawaban formulir bernomor urut tercetak digunakan untuk mengevaluasi bukti dokumenter yang mendukung kelengkapan catatan akuntansi.

8. Scanning

Scanning merupakan review secara cepat terhadap dokumen, catatan dan daftar untuk mendeteksi unsur-unsur yang tampak tidak biasa yang memerlukan penyelidika lebih mendalam. 
9. Pelaksanaan ulang (reperforming)

Prosedur audit ini merupakan pengulangan aktivitas yang dilaksanakan oleh klien. Umumnya pelaksanaan ulang ditetapkan pada perhitungan dan rekonsiliasi yang telah dilakukan oleh klien.

10. Teknik audit berbantuan computer (computer-assisted audit techniques).

Bilamana catatan akuntansi klien diselenggarakan dalam media elektronik, auditor perlu menggunakan computer-assisted audit techniques dalam menggunakan berbagai prosedur audit diatas.

\section{Kualitas Sumber Daya Manusia}

Kualitas SDM dapat ditingkatkan melalui pelatihan dan pemberian kompensasi yang adil termasuk berbagai fasilitas kesejahteraan karyawan. Beberapa Pengertian kualitas SDM yang dipaparkan oleh para ahli yaitu :

1. Menurut Soekidjo Notoatmodjo (2012) dalam buku "Pengembangan Sumber Daya Manusia" menyatakan bahwa Kualitas Sumber Daya Manusia adalah menyangkut dua aspek yaitu aspek fisik (kualitas fisik) dan aspek nonfisik (kualitas non-fisik) yang menyangkut kemampuan bekerja, berfikir dan keterampilan.

2. Menurut M. Dawam Raharjo (2012) dalam buku "Intelektual, Inteligensia dan prilaku politik bangsa" Kualitas SDM tidak hanya ditentukan oleh aspek keterampilan atau kekuatan tenaga fisiknya saja, akan tetapi juga ditentukan oleh pendidikan dan kadar pengetahuannya, pengalaman atau kematangannya dan sikapnya serta nilai-nilaiyang dimilikinya.

3. Menurut Robbins (dalam Enifah, 2012) kualitas SDM dapat diukur dari keberhasilan peningkatan kemampuan teoritis, peningkatan kemampuan teknis, peningkatan kemampuan konseptual, peningkatan moral dan peningkatan keterampilan teknis.

4. Menurut Danim (2013) Kualitas SDM adalah sumber daya yang memenuhi kriteria kualitas fisik dan kesehatan, kualitas intelektual (pengetahuan dan keterampilan), dan kualitas mental spiritual (kejuangan).

\section{Pengelolaan Kualitas SDM}

Menurut Ed's (2010) mengelola kualitas SDM perusahaan pada dasarnya merupakan kegiatan perusahaan dalam mengelola para pegawainya (SDM). Rancangan setiap perusahaan tentu saja berbedabeda tergantung dari tujuan atau Beberapa hal perlu diperhatikan dalam pengelolaan SDM guna meningkatkan kualitas SDM dalam suatu organisasi antara lain (Schuller, 1990 dalam Ellitan 2010):

1. Mengelola SDM untuk menciptakan kemampuan.

2. Mengelola diversitas tenaga kerja untuk meraih keunggulan bersaing.

3. Mengelola SDM untuk meningkatkan daya saing.

4. Mengelola SDM untuk menghadapi globalisasi. 


\section{Etika Profesi}

Definisi etika profesi secara umum menurut Arens yang dialihbahasakan oleh Herman Wibowo (2011:71-91) adalah : "Standar-standar, prinsip-pirinsip, interprestasi atas peraturan etika, dan kaidah etika yang harus dilakukan seorang auditor seperti Tanggung jawab profesi, kepentingan publik, integritas, obyektifitas auditor, keseksamaan dan lingkup dan sikap jasa dalam memeriksa laporan keuangan".

Indikator Etika Profesi menurut Hiro Tugiman (2011) :

1. Tanggung jawab, Moral, Sosial dan Professional.

2. Mengetahui Kejujuran.

3. Mengetahui prinsip Kerahasian

4. Mengetahui prinsip Objektifitas dan Integritas

\section{Prinsip Etika Profesi}

Menurut Sukrisno Agoes (2012:43) Prinsip prinsip etika yang dirumuskan IAPI dan dianggap menjadi kode etik perilaku akuntan Indonesia sebagai berikut :

1. Tanggung Jawab Profesional

Dalam melaksanakan tanggung-jawabnya sebagai profesional setiap anggota harus senantiasa menggunakan pertimbangan moral dan profesional dalam semua kegiatan yang dilakukan.

2. Kepentingan Publik

Setiap anggota berkewajiban untuk senantiasa bertindak dalam kerangka pelayanan kepada publik, menghormati kepercayaan publik, dan menunjukkan komitmen atas profesionalisme.

2. Integritas

Untuk memelihara dan meningkatkan kepercayaan publik, setiap anggota harus memenuhi tanggung jawab profesionalnya dengan integritas setinggi mungkin.

3. Objektifitas

Setiap anggota harus menjaga objektivitasnya dan bebas dari benturan kepentingan dalam pemenuhan kewajiban profesionalnya.

4. Kompetensi dan Kehati-hatian Profesional

Setiap anggota harus melaksanakan jasa profesionalnya dengan kehati-hatian, kompetensi dan ketekunan, serta mempunyai kewajiban untuk mempertahankan pengetahuan dan keterampilan profesional pada tingkat yang diperlukan untuk memastikan bahwa klien atau pemberi kerja memperoleh manfaat dari jasa profesional yang kompeten berdasarkan perkembangan praktik, legislasi dan teknik yang paling mutakhir.

5. Kerahasiaan

Setiap anggota harus, menghormati kerahasiaan informasi yang diperoleh selama melakukan jasa profesional dan tidak boleh memakai atau mengungkapkan informasi tersebut tanpa persetujuan, kecuali bila ada hak atau kewajiban profesional atau hukum untuk mengungkapkannya.

6. Perilaku Profesional

Setiap anggota harus berperilaku yang konsisten dengan reputasi profesi yang baik dan menjauhi tindakan yang dapat mendiskreditkan profesi. 
7. Standar Teknis

Setiap anggota harus melaksanakan jasa profesionalnya sesuai dengan standar teknis dan standar profesional yang relevan. Sesuai dengan keahliannya dan dengan berhati-hati, anggota mempunyai kewajiban untuk melaksanakan penugasan dari penerima jasa selama penugasan tersebut sejalan dengan prinsip integritas dan obyektivitas.

\section{Komitmen Organisasi}

Pengertian Komitmen Organisasi Komitmen sering dikaitkan dengan keadaan dimana seorang pegawai memihak organisasi tertentu serta tujuan-tujuan dan keinginannya untuk mempertahankan keanggotaaan dalam organisasi tersebut. Dibawah ini merupakan beberapa pengertian komitmen organisasi menurut para ahli :

Khaerul Umam (2010:259) bahwa : 18 "komitmen organisasi memiliki arti penerimaan yang kuat dalam diri individu terdapat tujuan dan nilai-nilai organisasi, sehingga individu tersebut akan berkarya serta memiliki keinginan yang kuat untuk bertahan di organisasi” (2014) :

Indikator Komitmen Organisasi menurut Robbins, Stephen P. dan Timothy A. Judge

1. Memiliki kepercayaan, menerima tujuan dan nilai organisasi.

2. Berkeinginan untuk berusaha ke arah pencapaian tujuan organisasi.

3. Memiliki keinginan yang kuat untuk bertahan sebagai anggota organisasi.

\section{Manfaat Komitmen Organisasi}

Manfaat Komitmen Organisasi menginginkan agar seluruh pegawai memiliki komitmen organisasi yang tinggi, manfaat komitmen pegawai bagi organisasi, yaitu :

1. Menghindari biaya pergantian pegawai yang tinggi Seseorang yang berkomitmen tidak menyukai untuk berhenti dari pekerjaannya dan menerima pekerjaan lainnya. Ketika seorang pegawai berkomitmen maka tidak akan terjadi pergantian pegawai yang tinggi. Mengurangi atau meringankan supervise pegawai Pegawai yang berkomitmen dan memiliki keahlian yang tinggi akan mengurangi keperluan supervise terhadapnya. Supervise yang ketat dan pengawasan yang melekat akan membuang-buang waktu dan biaya.

2. Meningkatkan efektifitas organisasi Penelitian menunjukan bahwa ketiadaan komitmen dapat mengurangi efektivitas organisasi. Sebuah organisasi yang pegawainya memiliki komitmen organisasi akan mendapatkan hasil yang diinginkan seperti kinerja tinggi, tingkat pergantian pegawai rendah dan tingkat ketidak hadiran yang rendah. Selain itu juga akan menghasilkan hal lain yang diinginkan yaitu iklim organisasi yang hangat, mendukung menjadi anggota tim yang baik dan siap membantu (Fred Luthas 2012).

\section{Pilar-Pilar Komitmen Organisasi}

Menciptakan Komitmen Organisasi Menurut Mangkunegara (2012:176) ada tiga pilar dalam menciptakan Komitmen organisasi, yaitu :

1. Adanya perasaan menjadi bagian dari organisasi. 
Untuk menciptakan rasa memiliki tersebut, maka salah satu pihak dalam manajemen harus mampu membuat pegawai :

a. Mampu mengidentifikasi dirinya terhadap organisasi.

b. Merasa yakin bahwa apa yang dilakukan atau pekerjaannya adalah berharga bagi organisasi.

c. Merasa nyaman dengan organisasi.

d. Merasa mendapat dukungan yang penuh dari organisasi dalam bentuk misi yang jelas (apa yang direncanakan untuk dilakukan), nilai-nilai yang ada (apa yang diyakini sebagai hal yang penting oleh manajemen), normanorma yang berlaku (cara-cara berperilaku yang bisa diterima oleh organisasi).

2. Adanya keterikatan atau kegairahan terhadap pekerjaan.

Perasaan seperrti itu dapat dimunculkan dengan cara :

a. Mengenali faktor-faktor motivasi dalam mengatur desain pekerjaan (job design).

b. Kualitas kepemimpian.

c. Kemampuan dari manajer dan supervisor untuk mengenali bahwa komitmen pegawai bisa mengingkatkan jika ada perhatian terus menerus, memberi delegasi atas wewenang serta memberi kesempatan dan ruang yang cukup bagi pegawai untuk menggunakan keterampilan dan keahlian secara maksimal.

3. Pentingnya rasa memiliki.

Rasa memiliki bisa muncul jika pegawai merasa bahwa mereka benar-benar diterima menjadi bagian atau kunci penting dari organisasi. Ikut sertakan keterlibatan pegawai dalam memuat keputusan dan jika mereka merasa ideidenya di dengar dan merasa telah memberikan kontribusi pada hasil yang dicapai, maka mereka akan cenderung menerima keputusan-keputusan atau perubahan yang dimiliki, hal ini dikarenakan mereka merasa dilibatkan dan bukan karena dipaksa.

\section{Kinerja Auditor}

\section{Faktor-Faktor yang Mempengaruhi Kinerja}

Dalam sebuah perusahaan ternyata kinerja pegawai yang satu dengan yang lainnya cenderung tidak sama, selalu ada perbedaan baik dalam kuantitas ataupun kualitas. Menurut Keith Davis dalam Mangkunegara (2013:67) kinerja (performance) dipengaruhi oleh tiga faktor, yaitu:

1. Faktor individual

Faktor individual yang terdiri dari kemampuan dan keahlian, latar belakang dan demografi.

2. Faktor psikologis

Faktor psikologis terdiri dari persepsi (attitude) sikap, personality, pembelajaran dan motivasi.

3. Faktor organisasi

\section{Evaluasi Kinerja}

Evaluasi kinerja dimaksudkan sebagai proses penilaian pelakasanaan tugas (performance) seseorang atau sekelompok orang atau unit-unit kerja dalam satu perusahaan atau organisasi sesuai dengan standar kinerja atau tujuan yang telah ditetapkan. Evaluasi kinerja disebut juga "performance evaluation" atau "performance appraisal" 
yang secara harfiah berarti memberi nilai atas pekerjaan yang telah dilakukan Simanjuntak, (2013:107). Simanjuntak (2013:19-24) menyatakan evaluasi kinerja adalah satu sistem dan cara penilaian pencapaian hasil kerja satu pemerintahan dan organisasi lainnya, penilaian hasil krja setiap individu yang bekerja di dalam dan untuk pemerintahan tesebut. Evaluasi atau pengukuran kinerja dapat dilakukan melalui beberapa tahapan:

1. Mengumpulkan dan menyeleksi informasi.

2. Mengembangkan dan mengkaji informasi.

3. Menarik kesimpulan

\section{Kinerja Auditor}

Kinerja auditor merupakan tindakan atau pelaksanaan tugas pemeriksaan yang telah diselesaikan oleh auditor dalam kurun waktu tertentu. Pengertian kinerja auditor menurut Mulyadi (2014) adalah akuntan publik yang melaksanakan penugasan pemeriksaan (examination) secara obyektif atas laporan keuangan suatu perusahaan atau organisasi lain dengan tujuan untuk menentukan apakah laporan keuangan tersebut menyajikan secara wajar sesuai dengan prinsip akuntansi yang berlaku umum, dalam semua hal yang material, posisi keuangan dan hasil usaha perusahaan.

\section{Desain Penelitian}

Desain penelitian yang digunakan adalah Penelitian Causal (Causal Reserch). Menurut Sugiyono (2016:37), penelitian kausal adalah penelitian yang bersifat sebab dan akibat. Digunakan untuk mengetahui pengaruh antara satu atau lebih variabel bebas (Independent Variable) terhadap variabel terikat (Dependent Variable). Variabel bebas (Independent Variable) adalah Kualitas SDM, Etika Profesi, Komitmen Organisasi dan variabel terikat (Dependent Variable) adalah Kinerja auditor. Berikut adalah kerangka pemikiran dalam penelitian ini :

\section{Variabel Independen}

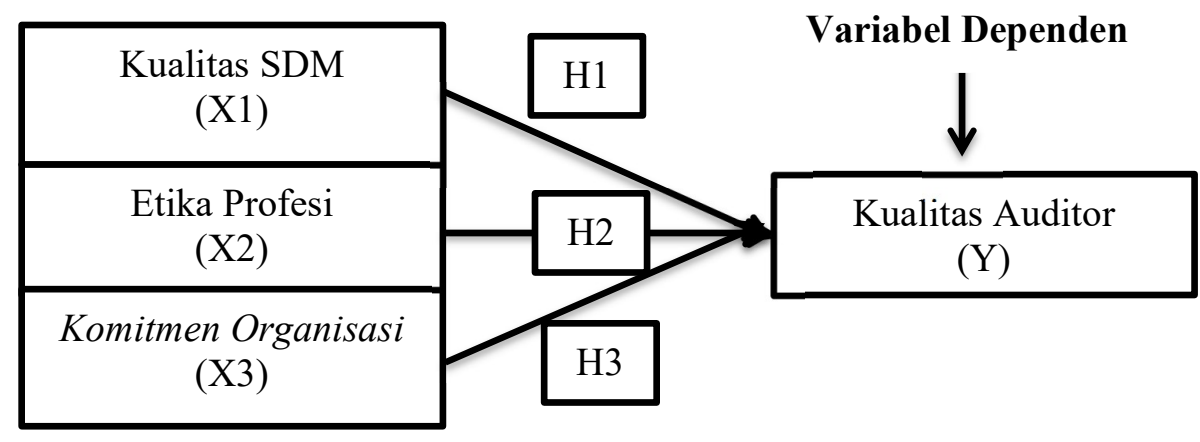

Gambar

Sumber: data diolah 2018

\section{Desain Penelitian}




\title{
METODOLOGI PENELITIAN
}

\author{
Waktu dan Tempat Penelitian \\ Waktu Penelitian \\ Penelitian ini dilaksanakan pada bulan april 2018 sampai dengan bulan Juli 2018.
}

\section{Tempat Penelitian}

Dalam penelitian ini, peneliti melakukan penelitian di Kantor Akuntan Publik (KAP) Jakarata Selatan. Jumlah KAP di daerah Jakarta Selatan yang terdaftar dalam IAPI 2017 sebanyak 94 KAP. Berdasarkan konfirmasi yang dilakukan peneliti, terdapat 10 KAP yang bersedia untuk mengisi kuesioner (penelitian). Berikut daftar KAP yang telah di konfirmasi dalam pelaksanaan penelitian :

\section{Variabel dan Skala Pengukuran Variabel Penelitian}

Variabel penelitian menurut Sugiyono (2016:38), adalah segala sesuatu yang berbentuk apa saja yang ditetapkan oleh peneliti untuk dipelajari sehingga diperoleh informasi tentang hal tersebut, kemudian ditarik kesimpulannya. Variabel-variabel dalam penelitian ini didefinisikan secara jelas sehingga tidak menimbulkan pengertian ganda. Dalam penelitian ini terdapat dua variabel yang terdiri dari satu variabel independen (variabel bebas) dan satu variabel dependen (variabel terikat). Peneliti akan menggunakan dua variabel yang akan diteliti, yaitu:

a. Variabel Independen (Variabel X)

Menurut (Sugiyono. 2016: 39), variabel independen disebut juga variabel bebas merupakan variabel yang mempengaruhi atau menjadi sebab perubahannya atau timbulnya variabel dependen (variabel terikat). Dalam penelitian ini yang menjadi variabel X adalah Kualitas SDM (X1), Etika Profesi (X2), Komitmen Organisasi (X3)

b. Variabel Dependen (Variabel Y)

Menurut (Sugiyono. 2016: 39), variabel dependen disebut juga variabel terikat, merupakan variabel yang dipengaruhi aatau yang menjadi akibat karena adanya variabel bebas, variabel Y dalam penelitian ini adalah Kinerja Auditor (Y).

\section{Jenis Data}

Dalam penelitian ini peneliti menggunakan data primer. Data primer adalah data yang diperoleh langsung dari objek yang diteliti yang digunakan untuk mengukur variabel independen (Kualitas SDM, Etika Profesi dan Komitmen Organisasi) serta variabel dependen (Kinerja Auditor) yang diambil dari individu atau perseorangan, seperti hasil pengujian kuesioner. 


\section{ANALISIS HASIL DAN PEMBAHASAN}

\section{Deskriptif Data}

\section{Interprestasi Hasil Penelitian Kualitas SDM (X1) Tidak Berpengaruh Terhadap Kinerja Auditor (Y)}

Berdasarkan hasil uji t menunjukkan bahwa thitung variable Kualitas SDM sebesar 1,508 dimana $t_{\text {hitung }}$ bernilai lebih kecil dari tabel sebesar 2,013 $(1,508<2,013)$ dan tingkat signifikan bernilai $0,138(0,138>0,05)$.

Kualitas sdm tidak mempengaruhi sdm karena Hal ini disebabkan kinerja auditor tidak semata-mata dipengaruhi oleh kualitas sdm di perusahaan akan tetapi dipengaruhi oleh kepemimpinan dan perhatian atasan. Kualitas sdm diperoleh bukan hanya dari lingkungan kerja yang ada namun lebih banyak ditentukan oleh budaya perusahaan yang kondusif. Kualitas sdm diperoleh bukan berasal dari restrukturisasi kerja perusahaan akan tetapi lebih banyak ditentukan oleh motivasi dari pimpinan atau atasan sehingga karyawan dalam bekerja akan meningkatkan kinerja dengan baik. Kesimpulan hasil penelitian ini memiliki sejumlah implikasi bagi pengembangan teori dan dapat digunakan sebagai acuan bagi penelitian yang akan datang. Hal ini menyebutkan bahwa sdm yang berkualitas ingin diperlakukan sebagai individu yang dihargai di tempat kerja. Kinerja yang bagus akan menghasilkan pekerja yang baik jika mereka dihargai dan diperlakukan seperti layaknya manusia dewasa. Dimensi inilah yang menjadi indikasi kuat bahwa kualitas sdm dianggap penting bagi pengembangan kualitas sdm bagi pekerja KAP, yaitu suasana kerja dan perkembangan karir, dukungan dari pihak manajemen, penghargaan dari perusahaan serta dampak kerja pada kehidupan personal.

Penelitian ini tidak sejalan dengan penilitan yang dilakukan oleh Rendy Ardiansyah (2017) yang mengatakan bahwa kualita sdm berpengaruh terhadap kinerja auditor.

\section{Etika Profesi $\left(\mathrm{X}_{2}\right)$ Tidak Berpengaruh Terhadap Kinerja Auditor (Y)}

Berdasarkan hasil uji t menunjukkan bahwa thitung variable Kompetensi sebesar -0,025 dimana $t_{\text {hitung }}$ bernilai lebih kecil dari $t_{\text {tabel }}$ sebesar $2,013 \quad(-0,025<2,013)$ dan tingkat signifikan bernilai 0,980 $(0,980>0,05)$. Dengan demikian, Etika Profesi tidak berpengaruh terhadap Kinerja Auditor.

Di Indonesia, etika akuntan menjadi isu yang sangat menarik. Hal ini seiring dengan terjadinya beberapa pelanggaran etika yang dilakukan oleh akuntan, baik akuntan independen, akuntan intern perusahaan maupun akuntan pemerintah. Tanpa etika, profesi akuntansi tidak akan ada karena fungsi akuntansi adalah penyedia informasi untuk proses pembuatan keputusan bisnis oleh para pelaku bisnis. Di samping itu, profesi akuntansi mendapat sorotan yang cukup tajam dari masyarakat. etika profesi sangatlah dibutuhkan oleh masing-masing profesi, untuk mendapatkan kepercayaan dari masyarakat, seperti profesi auditor. etika profesi meliputi suatu standar dari sikap para anggota profesi yang dirancang agar sedapat mungkin terlihat praktis dan realitis, namun tetap idealistis. Setiap auditor harus mematuhi etika profesi mereka agar tidak menyimpangi aturan dalam menyelesaikan laporan keuangan kliennya. Memahami peran perilaku etis seorang auditor dapat memiliki efek yang luas pada bagaimana bersikap terhadap klien mereka agar dapat 
bersikap sesuai dengan aturan akuntansi berlaku umum. etika berkaitan dengan perilaku moral dan berfungsi sebagai kontrol pelaksanaan suatu aktivitas. Maka dari itu etika hanya melihat dari sisi sikap kepribadian manusia tersebut bukan melihat dsri sisi kinerjanya.

Sejalan dengan penelitian yang dilakukan oleh Pungki Retno Pratiwi (2015) yang mendapatkan hasil bahwa etika profesi tidak berpengaruh terhadap kinerja auditor. Namun tidak sejalan dengan penelitian yang dilakukan oleh I Wayan Candra \& I Dewa Nyoman Badera (2017) yang mendapatkan hasil bahwa etika profesi berpengaruh terhadap kinerja auditor.

\section{Komitmen Organisasi $\left(\mathbf{X}_{3}\right)$ Berpengaruh Terhadap Kinerja Audior (Y)}

Berdasarkan hasil uji t menunjukkan bahwa $t_{\text {hitung variable Komitmen Organisasi }}$ sebesar 2,422 dimana thitung bernilai lebih besar dari tabel sebesar 2,013 $(2,422>2,013)$ dan tingkat signifikan bernilai 0,019 $(0,019<0,05)$. Dengan demikian, Komitmen Organisasi berpengaruh terhadap Kinerja Auditor.

Komitmen organisasi memiliki pengaruh terhadap kinerja auditor terbukti bahwa semakin tinggi rasa komitmen organisasi dapat meningkatkan kinerja. Dengan menumbuhkan rasa nyaman didalam organisasinya akan membuat senang dia berada dalam organisasinya terbukti dalam penelitian ini point dimana adanya keinginan untuk berusaha ke arah pencapaian tujuan organisasi, Memiliki kepercayaan, menerima tujuan dan nilai organisasi, Memiliki keinginan yang kuat untuk bertahan sebagai anggota organisasi.

Sejalan dengan penelitian yang dilakukan oleh Ni Made Regina Amandani \& Made Gede Wirakusuma (2017) yang mendapatkan hasil bahwa komitmen organisasi berpengaruh terhadap kinerja auditor. Namun tidak sejalan dengan penelitian yang dilakukan oleh Saputro Nugroho Widhi \& Dr. Erma Setyawati, Ak, M.M., (2015) yang mendapatkan hasil bahwa komitmen organisasi tidak berpengaruh terhadap kinerja auditor. 


\section{PENUTUP}

\section{Kesimpulan}

Berdasarkan hasil penelitian seperti yang telah diuraikan sebelumnya, dapat ditarik kesimpulan secara parsial yaitu :

1. Kualitas SDM tidak berpengaruh positif dan signifikan terhadap Kinerja Auditor di Kantor Akuntan Publik Jakarta Selatan. Dapat dilihat dari t hitung lebih kecil jika dibandingkan $\mathrm{t}$ table $(1,508<2,003)$ serta nilai signifikansi Kualitas SDM terhadap Kinerja Auditor lebih besar dari nilai signifikansi $(0,138>0,05)$ sehingga menolak H1.

2. Etika Profesi tidak berpengaruh positif dan signifikan terhadap Kinerja Auditor di Kantor Akuntan Publik Jakarta Selatan. Dapat dilihat dari t hitung lebih kecil jika dibandingkan $t$ table $(-0,025<2,003)$ serta nilai signifikansi Etika Profesi terhadap Kinerja Auditor lebih besar dari nilai signifikansi $(0,980>0,05)$ sehingga menolak H1.

3. Komitmen Organisasi berpengaruh positif dan signifikan terhadap Kinerja Auditor di Kantor Akuntan Publik Jakarta Selatan. Dapat dilihat dari t hitung lebih besar jika dibandingkan $t$ table $(2,422>2,003)$ serta nilai signifikansi Profesionalisme terhadap Kinerja Auditor lebih besar dari nilai signifikansi $(0,019<0,05)$ sehingga menerima H1.

4. Sebesar 34,5\% variable Kualitas SDM, Etika Profesi, Komitmen Organisasi memiliki pengaruh terhadap Kinerja Auditor. Sedangkan 65,5\% dapat dipengaruhi oleh variabel-variabel lain yang tidak termasuk dalam penelitian ini, seperti Pengetahuan, Keahlian, Tipe Kepribadian, Independensi, dll. 


\section{DAFTAR PUSTAKA}

Agoes, Sukrisno. (2016). Auditing Petunjuk Praktis Pemeriksaan Akuntan oleh Akuntan Publik Edisi 4. Jakarta: Salemba Empat.

Agoes, Sukrisno. Ardana, Cenik. 2013, Etika Bisnis dan Profesi Tantangan. Membangun manusia seutuhnya. Jakarta:Salemba Empat.

Anderson, Lorin. W dan David R. Krathwohl (Ed's). (2010). Kerangka Landasan untuk Pembelajaran, Pengajaran, dan Asesmen: Revisi Taksonomi Pendidikan Bloom. Penerjemah: Agung Prihantoro. Yogyakarta: Pustaka Pelajar.

Arens, Alvin A., et al. 2011. Auditing dan Jasa Assurance. Jakarta: Erlangga. Alih Bahasa: Herma Wibowo. Editor: Wibi Hardani, dan Suryadi Saat.

Arens, A.A. et al. 2012. Jasa Audit dan Assurance. Edisi 14. Jakarta: Salemba Empat.

Anwar Prabu Mangkunegara, 2013, Manajemen Sumber Daya Manusia Perusahaan, Remaja Rosdakarya, Bandung.

Anwar Prabu Mangkunegara. 2012. Perilaku dan Budaya Organisasi. Bandung : PT. Rafika Aditama.

Danim, Sudarwan, Menjadi Peneliti Kualitatif, Bandung: CV Pustaka Setia, 2013.

Darmawan, D. 2013. Prinsip-prinsip Perilaku Organisasi. Surabaya: PT. Temprina Media Grafika.

Ghozali, Imam, 2013. Aplikasi Analisis Multivariat dengan Program IBM SPSS 21. Edisi 7, Penerbit Universitas Diponegoro, Semarang.

Ghozali, Imam. (2016). Aplikasi Analisis Multivariate Dengan Program IBM SPSS 23. Semarang: Badan Penerbit Universitas Diponegoro.

Khaerul. Umam. 2010. Perilaku Organisasi. Bandung: Pustaka Setia.

Luthans, Fred.2012."Perilaku Organisasi" edisi 10.Yogyakarta:Penerbit ANDI.

Mangkunegara AP, 2015, Perencanaan dan Pengembangan Sumber Daya Manusia, Refika Aditama, Bandung.

Moeheriono. 2012. "Pengukuran Kinerja Berbasis Kompetensi”. Jakarta: Raja Grafindo Persada.

Mulyadi. 2014. Auditing Edisi 6. Jakarta: Salemba Empat.

Ndraha, Taliziduhu, 2012, Pengantar teori Pengembangan Sumber Daya Manusia, Rineka Cipta, Jakarta.

Notoatmodjo, Soekidjo, 2012, Pengembangan Sumber Daya Manusia, Jakarta: PT. Rineka Cipta. 
Raharjo M. Dawam 2012. Intelektual, Intelegensia dan prilaku politik bangsa. Mizan, Bandung.

Robbins, Stephen P. dan Timothy A. Judge. 2014. Perilaku Organisasi Edisi ke-16, Jakarta: Salemba Empat.

Simanjuntak, Timbul Hamonangan. 2013. Dimensi Ekonomi Dalam Pembangunan Ekonomi. Bogor : Penerbit Raih Asa Sukses.

Sugiyono. (2016). Metodologi Penelitian Kuantitatif, Kualitatif, dan R\&D. Bandung: CV Alfabeta.

Sugiyono. (2015). Metode Penelitian Kuantitatif Kualitatif R\&B. Bandung: Aflabeta.

Sujarweni, V. Wiratna. (2015). Sistem Akuntansi. Yogyakarta : Pustaka Baru Press.

Tugiman, Hiro. (2013). Standar Profesional Audit Internal. Kansius : 2011.

Amandani, N, M, R., \& Made, G.W. 2017. Pengaruh Komitmen Organisasi, Gaya Kepemimpinan dan Pelatihan Profesi pada Kinerja Auditor. Jurnal Akuntansi Universitas Udayana.

Chandra, I. W., \& Badera, I.N.D. (2017). Pengaruh Komitmen Organisasi, Gaya Kepemimpinan Demokratis, Etika Profesi dan Pengalaman Auditor Pada Kinerja Auditor. Jurnal Akuntansi.

Enifah, Ernik. 2012. Strategi Peningkatan Kualitas Sumber Daya Manusia Sebagai Upaya Memaksimalkan Produktivitas Perusahaan. Skripsi. Institut Agama Islam Negeri Walisongo Semarang.

Elilitan, Lena. (2010). Praktik-praktik Pengelolaan Sumber Daya Manusia dan Keunggulan Kompetitif Berkelanjutan. Jurnal Manajemen \& Kewirausahaan. Vol 4, No. 2.

Kesuma, et.al (2015). Pengaruh Kompensasi, Pendidikan dan Pelatihan, Program Keselamatan dan Kesehatan Kerja terhadap Kinerja Karyawan di Hotel Kuta Paradiso Kuta, Bandung. Jurnal. Vol 4. No. 2.

Nainggolan, Andreas Sofyan. 2012. Pengaruh Persepsi Mahasiswa Akuntansi Mengenai Undang-Undang Akuntan Publik dan Etika Profesi Akuntan Publik Terhadap Persepsi Mengenai Pilihan Kariernya Sebagai Akuntan Publik. Skripsi. Universitas Negeri Semarang.

Rendy, A., \& Akhmad, R (2017). Pengaruh Kualitas SDM, Komitmen Organisasi dan Penggunaan Teknologi SIA pada Kinerja Auditor. Jurnal Akuntansi.

Roshanti, A. Edy S, Kadek S. 2014. Pengaruh Kualitas SDM, Pemanfaatan TI, dan Sistem Pengendalian Intern Terhadap Nilai Informasi Pelaporan Keuangan Pemerintah Daerah. Journal. Universitas Pendidikan Ganesha 
Suwanda, D. (2015). Factors affecting quality of local government financial statements to Get Unqualified Opinion (WTP) of Audit Board of Republik Indonesia (BPK). Research Journal of Finance and Accounting, 6 (4), 139-157.

Wansyah et al. 2012. Pengaruh Kapasitas Sumber daya Manusia, Pemanfaatan Teknologi Informasi dan Kegiatan Pengendalian Terhadap Nilai Informasi Pelaporan Keuangan SKPD pada Provinsi Aceh. Jurnal Akuntansi. Vol. 01 No.01.

Pratiwi, P, R. 2015. Pengaruh Independensi, Profesionalisme, dan Etika Profesi Terhadap Kinerja Auditor Pada Kantor Akuntan Publik Surakarta dan Yogyakarta. Jurnal Akuntansi.

Widhi, S, N., \& Erma, S. 2015. Pengaruh Independensi, Gaya Kepemimpinan, Komitmen Organisasi dan Pemahaman Good Governance Terhadap Kinerja Auditor Pemerintah. Jurnal Manajemen dan Bisnis. 